\title{
Szabó Ferenc* \\ Az önkormányzati együttmüködés zavarai \\ a Szeged Regionális Hulladékgazdálkodási ISPA projekt üzemeltetésének kezdeti szakaszában
}

\begin{abstract}
SUMMARY
On the basis of a case study I present the experiences of the operation and the typical operational conflicts of the completed Hungarian EU environmental infrastructure development projects, first of all from the aspect of the cooperation of the beneficiary local governments. In the analyzed case - ,Szeged Regional Waste Management Program" ISPA project - the legal beneficiary is the municipality of Szeged, but the other 32 municipalities of the region are also interested in the successful implementation of the project and are responsible for the continuous long run operation.
\end{abstract}

\section{BEVEZETÉS}

A „Szeged Regionális Hulladékgazdálkodási Programja" elnevezésü Kohéziós Alap (korábban ISPA) projekt beruházási munkái befejezỏdtek, a próbaüzemeket és üzempróbákat követően megtörtént müszaki átadás-átvétel és megkezdődött az üzemeltetés időszaka. E projekt vizsgálata alapján szeretném bemutatni a hazai európai uniós környezetvédelmi infrastruktúra fejlesztési projektek keretében megvalósult beruházások üzemeltetési tapasztalatait és az üzemeltetés során jelentkező tipikus konfliktusokat, most elsősorban a kedvezményezett önkormányzatok viszonyrendszerében. A kedvezményezett önkormányzat a vizsgált esetben jogilag Szeged megyei Jogú Város, azonban a térség további 32 települése ugyancsak érintett a projekt megvalósításában és felelösséggel tartozik annak hosszú távú folyamatos müködéséért.

A projekt tervezés és előkészítés, továbbá a közbeszerzési eljárás lebonyolítását és a szerzőkötést követöen kezdetét veszi a koncentrált eröforrás-lekötést és felhasználást igénylő tényleges megvalósítás, ahol a tervezés (kiviteli tervek és a megvalósult állapotrögzítỏ tervek), az építés-szerelés és próbaüzem a szakmai sajátosságoknak megfelelő müszaki-gazdasági törvényszerüségek szerint lezajlanak. A létesítmény megvalósítás folyamatának ez a szakasza közvetlenül eredményezi magát a fizikailag is kész - üzemszerü müködésre, vagy használatra alkalmas - termelö- vagy szolgáltató létesítményt (Görög, 2001). A projektmenedzsment tudomány hangsúlyt helyez üzemeltetés tapasztalatainak elemzésére, értékelésére, amely fontos része az utóellenörzésnek. Az önkormányzatok közötti együttmüködés zavarai, konfliktusai jól jellemzik a mai hazai környezetvédelem és ezen belül a hulladékgazdálkodás sajátos helyzetét.

\section{KUTATÁSI EREDMÉNYEK}

A projekt elökészítés időszakához viszonyítva mára jelentősen megváltoztak a müködtetésre vonatkozó elképzelések, feltételek és szempontok. Különösen a közbeszerzési szabályok erőteljes megváltozása, a közbeszerzési törvény hatályba lépése teremtett új helyzetet az üzemeltetési feltételekben.

\footnotetext{
• Óraadó, környezetvédelmi szakmérnök - SZTE Mérnöki Kar.
} 


\subsection{A projekt létesitmények üzemeltetését végzõ közszolgáltató kiválasztása}

Szeged megyei jogú város Önkormányzata, mint a térség 33 települése által létrehozott hulladékgazdálkodási konzorcium gesztora, a projekt „,kedvezményezettjeként” tulajdonába kapta a projekt megvalósitása során - EU és hazai kormánytámogatással - létrejött közszolgáltatói vagyont. Ennek üzemeltetésére a közbeszerzési törvény elöirásainak megfelelően nyilvános pályázatot kell kiírni, melynek célja a létesítmények hosszú távú üzemeltetésre alkalmas közszolgáltató kiválasztása. Tekintettel arra, hogy a fejlesztések eredeti célja egy integrált térségi hulladék gazdálkodási rendszer létrehozása volt, melynek csak részterületeit öleli fel a projekt hulladékgazdálkodás fejlesztési célkitüzései, egy esetlegesen a közbeszerzési törvény elöirásainak ugyan megfelelö, de egyébként „rendszeridegen” (elsősorban üzleti alapon müködö) szolgáltató bevonása súlyos zavarokat, és feltételezhetően jelentős többletköltséget okozna. Az alapszolgáltatások, a hulladékok kezelésével kapcsolatos helyi közszolgáltatás (a települési szilárd hulladékok begyüjtése, szállítása, ártalmatlanítása, hasznositása), bár szorosan kapcsolódik az ISPA projekt keretében megvalósult rendszer müködéséhez, alapvetően nem része annak. Az üzemeltetés során ez azért jelent problémát, mert a közszolgáltatás és egyben a térségi hulladékgazdálkodási rendszer finanszírozásának fedezetét a helyi közszolgáltatás díjbevétele biztosítja.

Ha az ISPA fejlesztések üzemeltetése teljesen elkülönül az alapszolgáltatások ellátásától a megfelelö színvonalú folyamatos finanszírozás kérdései mellett óhatatlanul szakmai problémák is felmerülnek, hiszen az alapszolgáltatást ellátó és az uniós fejlesztéseket üzemeltető közszolgáltatók között komoly érdekellentétek, érdekütközések fognak jelentkezni. Ezért a kedvezményezett Szeged Megyei jogú város önkormányzata arra az álláspontra helyezkedett, hogy a közbeszerzési törvény által biztosított kivételek egyikével élve, a 100\%-os önkormányzati tulajdonban lévő szegedi hulladékgazdálkodási közszolgáltató non-profit korlátolt felelösségü társaságot közbeszerzési eljárás lefolytatása nélkül kijelöli az ISPA fejlesztések üzemeltetésére. A non-profit kft.(továbbiakban kijelölt üzemeltető) végezte megbizott projekt menedzser szervezetként az előkészítés és megvalósítás során a projekt bonyolitását, önkormányzati részröl történö koordinálását, irányítását.

\subsection{A projekt egyoldalú finanszírozása (kódolt konfliktusok és feszültségek)}

Szeged esetében 2000 és 2008 között az infláció feletti 10\%-os dijemelésre került sorminden évben, melynek eredményeként a helyi hulladékszállítási közszolgáltatás díja reálértékben a duplájára emelkedett. Ez a többletbevétel biztositotta a beruházás idöszakában a szükséges önkormányzati saját erő folyamatos rendelkezésre állását (melyet Szeged teljes egészében magára vállalt), az üzemeltetés idöszakában pedig a magasabb színtü szolgáltatás ellátásához szükséges többletforrásokat biztosítja. Erre a dijemelésre nem került sor a térség más településein, ezért jelentös különbségek alakultak ki viszonylag egymáshoz közeli települések esetében is.

Tekintettel arra, hogy a közszolgáltatói vagyon formálisan is Szeged tulajdonába került a fejlesztésekhez szükséges önerö biztositása indokolható volt. Az üzemeltetés esetében azonban már semmilyen indokkal sem tartható fenn az, az állapot, hogy ugyanazért a szolgáltatásért egymástól 10-15 km-re fekvö települések lakossága 50-70\%-kal többet, vagy kevesebbet fizessen (ráadásul a nagyobb szállitási távolságban lévök rendre kevesebbet fizetnek). Összegezve nem tartható fenn az, az állapot, mely a projekt megvalósitás során alakultak ki, azaz, hogy a szegedi lakosság fizesse meg a térség más településeinek lakossága helyett, a magasabb szintü helyi közszolgáltatás többletköltségeit. 


\subsection{A feszültségek forrásai}

A jelenlegi helyzet összetett, és feszültséget több tényező is okozza, melynek elsödleges forrása, hogy végül még, egyenlöre nem jött létre az egységes hulladékgazdálkodási régió. $\mathrm{Az}$ alapszolgáltatásokat több helyi közszolgáltató látja el, melyek korábban teljesen eltérỏ szemléletú és tartalmú szolgáltatást nyújtottak, melynek következtében kialakult a jelenlegi inkoherens térségi közszolgáltatási dijak rendszere.

\subsubsection{A szegedi közszolgáltatás}

A szegedi közszolgáltató az önkormányzat tulajdonában lévő non-profit kft, Szegeden és a csatolt településeken realizálta a szegedi önkormányzat által megállapított magasabb dijakat, amelyekből elkülönitésre került a projekt saját forrása. Az önerö pénzügy-technikailag bérleti dij formájában került át az önkormányzat költségvetésébe, amely a közvetlen finanszirozást biztosította.

\subsubsection{A szegedi közszolgáltató térségi tevékenysége}

A non-profit kft. további települések részére is végzett, végez hasonló tartalmú közszolgáltatást, de tekintettel arra, hogy ezeket a szerződéseket közbeszerzési pályázatokon nyerte el, az ezek esetében alkalmazott dijak értelemszerüen a szegedinél lényegesen alacsonyabbak. (A megemelt szegedi dijakkal egyetlen közbeszerzési pályázatot sem lehetett volna megnyerni.)

\subsubsection{Hulladékgazdálkodási cégcsoport létrehozása}

Az egyik érintett (részben más megyei önkormányzatok tulajdonában lévő) versenytárs (kft.) többségi tulajdonának felvásárlásával a non-profit kft. 2006-ban jelentős lépést tett az egységes regionális hulladékgazdálkodási rendszer megvalósitása felé, hiszen a szakmai követelményrendszert és a szolgáltatások tényleges müszaki tartalmát sikerült összehangolni. Ez a lépés azonban önmagában nem oldotta fel az eltérö mértékü dijak által okozott feszültségeket, sőt tovább növelte azokat, de már a cégcsoporton belül. A cégcsoport azt a célt tüzte ki, hogy legfeljebb 5 éven belül megkísérlik, az érintett önkormányzatokkal szorosan együttmüködve, az egységes dijrendszer megvalósítását, egyfajta térségi tarifaközösség létrehozását, melyen belül az egyes településeken alkalmazott szolgáltatási dijak mértéke legfeljebb 10\%-kal tér el egymástól. (Az utóbbi két évben, a korábbi helyzethez képest már jelentős elörelépés történt ezen a területen.)

\subsubsection{Egyéb közszolgáltatók a térségben}

Nehezebben kezelhető és a legnagyobb feszültségforrás egy harmadik, magántulajdonú szolgáltató jelenléte a térségben. Az érintett önkormányzatok ragaszkodnak saját szolgáltatójukhoz, feltehetően abból a téves megítélésből kiindulva, hogy az alacsony szolgáltatási ár neki köszönhetö. Valójában a szolgáltatás színvonala és tartalma teszi lehetővé a vállalkozónak az alacsonyabb ár érvényesítését. Az ISPA projekt befejezése és az üzemeltetési szakasz beindulása minden tekintetben új helyzetet idézett elö. A jövöben nincs lehetöség 
eltérö színvonalú és tartalmú közszolgáltatás megvalósitására. Ez azt jelenti, hogy a helyi közszolgáltatóknak, tulajdonostól függetlenül közel azonos szinvonalú és tartalmú szolgáltatást kell nyújtani. Igénybe kell venni az utólagos müszaki védelemmel ellátott, szigetelt regionális hulladéklerakó telepet, (Bár a régi falusi szeméttelepek rekultivációja még nem kezdődött el, de azokat már évekkel ezelött lezárták.) müködtetni kell a szelektív hulladékgyüjtő hálózat hulladékudvarait és gyüjtöszigeteit. Ez jelentős többletköltséget eredményez, hiszen a hulladékkezelés költségszerkezetében a begyüjtés és szállitás költsége legfeljebb 30\%. Az EU elöirásoknak megfelelö szigetelt depón történö biztonságos lerakás, továbbá a szelektiv hulladékgyüjtés és egyéb hulladékkezelési létesítmények (válogató üzem, komposztáló, építési törmelék feldolgozó stb.) üzemeltetési költségei teszik ki a hulladékgazdálkodás költségeinek, több mint kétharmadát. Ott ahol eddig gyakorlatilag csak a szállítás költségeit kellett megfizetni, a költségnövekedés 2-3-szoros is lehet.

\subsection{A hulladékgazdálkodás-fejlesztéssel kapcsolatos üzemeltetési többletköltségek finanszirozása}

Az üzemeltetés során felmerült, elsősorban a hulladék szigetelt depón történö rendezett lerakása és a szelektív hulladékgyüjtés (gyüjtösziget, hulladékudvar) megvalósítása miatt jelentkező jelentős többletköltség érvényesitése a helyi közszolgáltatás dijának keretén belül célszerü, hiszen ezek a hulladékkezelési helyi közszolgáltatás elválaszthatatlan részét képezik.

\subsubsection{A többletköltségek érvényesitése az önkormányzati érdekeltségủ közszolgáltatók esetében}

A szegedi önkormányzat közvetlen és közvetett többségi tulajdonában lévö két szolgáltató a többletköltségeket díjpolitikája részeként, középtávú stratégia keretében - az érintett önkormányzatokkal egyeztetve - fokozatosan beépíti a közszolgáltatási dijakba és így ezek a díjak fokozatosan közelítik a már korábban jelentősen megemelt szegedi díjakat.

\subsubsection{A többletköltségek érvényesitése a magánkézben lévõ helyi közszolgáltató esetében}

A magánkézben lévő szolgáltató esetében az, az elvi megállapodás született, hogy az önkormányzatok és a kijelölt közszolgáltató évente megállapodik a felmerülö többletköltség mértékében, melyet utólagos elszámolással kontrollálnak és a ténylegesen felmerült költségek alapján szükség szerint kơrrigálnak. A megállapított költséget a helyi közszolgáltató beépíti a közszolgáltatási dijjba és a regionális lerakó telepi elhelyezés során, az egyedileg megállapított lerakási díjon keresztül fizeti meg a kijelölt közszolgáltatónak.

Az elvi megállapodás megvalósítása során azonban komoly viták alakultak ki a többletköltségek várható alakulásának tekintetében. A kijelölt közszolgáltató által készített elözetes kalkulációkat az érintett önkormányzatok nem fogadták el, melynek következtében részben patt helyzet alakult ki.

\section{a) Viták az amortizáció kérdéskörében}

Első körben az egyes településeken megvalósuló hulladékudvarok amortizációjának kérdése, mértékének megállapitása volt, amelyet az önkormányzatok kifogásoltak. Aránytalanul magasnak itélték a bekerülési költségeket és az elszámolási rátákat. Tekintettel arra, hogy a beruházás szabályos közbeszerzési eljárás keretében valósult meg, a bekerülési 
költség utólagos megvitatására vagy jóváhagyására semmilyen lehetőség nincs. Az elszámolási rátákat pedig a mindenkor érvényes hazai pénzügyi és számviteli szabályok határozzák meg. (Az EU a támogatások felhasználásának utóellenőrzése során kiemelten vizsgálja a fejlesztések során létrejött létesítmények esetében a kedvezményezettek által alkalmazott amortizációs politikát. Érthető okok miatt, a hosszú távú üzemeltetés kiemelt feltételének tekintik.) A KvVM Fejlesztési Igazgatóságának közbenjárásával végül sikerült elfogadtatni az önkormányzatokkal, hogy az amortizációs költségek szabályszerü elszámolása megkerülhetetlen.

\section{b) Viták a várható üzemeltetési költségekrôl és a költségcsökkentés lehetőségeiröl}

Ezt követōen a várható üzemeltetési költségek kerültek a vita középpontjába. A szükséges karbantartási költségeket, az indokolt és célszerủ nyitvatartási időt és a szállitási költségek elözetes kalkuláció szerinti mértékét nem fogadták el az önkormányzatok. Felajánlották, hogy a szükséges karbantartásokat saját költségükre térítésmentesen elvégzik, a hu!ladékudvar kezelő személyzetét közhasznú, vagy közcélú foglalkoztatás keretében biztosítják, és a hulladékudvarba beszállított hulladék téritésmentes elszállitását is biztosítják, helyi vállalkozók segítségével. A kijelölt közszolgáltató jelezte, hogy elsősorban a közbeszerzési előírások miatt a hulladékudvarok üzemeltetésével kapcsolatos javaslatok csak részben megvalósíthatók, ezek jogi hátterének további vizsgálata szükséges. Nem zárkóznak el a költségcsökkentés egyetlen lehetséges módjától sem, de minden esetben, szerzödésben szükséges rögziteni a felek jogait és kötelezettségeit. Továbbá ragaszkodnak ahhoz, hogy a ténylegesen felmerült költségek pontos elszámolásával, legalább utólagosan kerüljön kiegyenlítésre a csak az érintett település lakossága által igénybe vett hulladékudvar költsége.

\subsubsection{Kompromisszum az üzemeltetés mielöbbi megkezdése érdekében}

Végül ugyancsak a KvVM Fejlesztési Igazgatóságának közbenjárásával az a megállapodás született, hogy a 2009 évi költségek a reálisnál lényegesen alacsonyabb szinten kerülnek meghatározásra, melyek utólagos korrekciójára valószinủleg csak 2010-ben kerül majd sor. Ez azt jelenti, hogy a ténylegesen felmerülö többletköltségek egy jelentős részét, még 2009ben is a szegedi lakosság fogja megelölegezni, néhány kömnezö település részére.

Szeged önkormányzata és a kijelölt üzemeltető azért kényszerült elfogadni ezeket a számára előnytelen kompromisszumokat, mert a projekt zárás időpontjáig, 2009. június 30-ig le kell zárni a függöben lévő vitás kérdéseket, valamennyi létesitmény esetében biztositani kell a folyamatos mủködés tárgyi, személyi és pénzügyi feltételeit, tisztázni kell a projekt tulajdonviszonyait, jogi hátterét és meg kell kötni minden szükséges szerződést, amelyek összességében biztositják a projekt hosszú távú, folyamatos mủködtetését és a projektcélok maradéktalan megvalósítását.

A hulladékudvarok mủszaki átadása már 2008 I. félévében megtörtént és a vitatott esetekben - a megegyezés hiánya miatt - még mindig nem kezdődött meg a folyamatos üzemeltetés. Ez a tény egy esetleges uniós ellenőrzés során komoly szankciókat vonhat maga után. 


\section{3. ÖSSZEGZÉS, KÖVETKEZTETÉSEK}

A tervezés, előkészítés, a közbeszerzési eljárás, valamint az egyes tenderek megvalósulási tapasztalatainak vizsgálatát követỏen a „Szeged Regionális Hulladékgazdálkodási Programja" elnevezésủ ISPA/Kohéziós Alap projekt kertében beszerzett eszközök, megvalósult létesitmények üzemeltetési tapasztalatait vizsgáltam a kedvezményezett önkormányzatok együttmüködésének szemszögéből. Elsősorban az egyes csatlakozó önkormányzatok területén megvalósult, az érintett települések lakossága által közvetlenül igénybe vett létesítmények üzemeltetési feltételeinek biztositása okoz konfliktusokat a kijelölt üzemeltető és az önkormányzatok között. A magasabb szintü közszolgáltatás és ezen belül is a szelektív hulladékgyüjtés (hulladékudvarok és gyüjtőszigetek üzemeltetése) jelentős többletköltséggel jár, melyet egyértelmủen a kötelező hulladékszállítási közszolgáltatást igénybe vevő lakosságnak kell megfizetnie. Az önkormányzatok többsége most szembesült azzal a évek óta elörelátható, nyilvánvaló ténnyel, hogy elkerülhetetlen a lakossági díjak jelentős mértékủ emelése. Amíg Szeged önkormányzata az elmúlt 7-8 évben reálértékben kétszeresére emelte közszolgáltatási dijait - mert kénytelen volt elöfinanszírozni a fejlesztések önerejét - addig a többi önkormányzat legfeljebb inflációval arányos dijemeléseket hajtott végre. (A többletterhek ellenértékeként Szeged tulajdonába került a támogatással létrejött teljes közszolgáltatói vagyon.)

$\mathrm{Az}$ üzemeltetés időszakában azonban tovább nem tartható az, az állapot, hogy közel azonos színvonalú és müszaki tartalmú szolgáltatásért egymáshoz viszonylag közel fekvő települések lakossága aránytalanul eltérő dijat fizessen. Szeged lakossága kénytelen volt magára vállalni az elökészítés és megvalósítás összes terhét, az üzemeltetés időszakában semmilyen indokkal sem támasztható alá, hogy szegediek fizessenek meg más településeken felmerülö bármilyen hulladékgazdálkodási költséget. Az eltérő dijjak jelentős feszültséget okoznak az egyes önkormányzatok és az egyes települések lakosságai között, és elkerülhetetlen a dijak kiegyenlitésének folyamata, ami azonban újabb és újabb feszültségek és konfliktusok forrása. Szeged példája bizonyítja, hogy átgondolt, jól ütemezett, kiszámítható középtávú dijpolitikával, amely a lakosság teherviselő képességét is igyekszik figyelembe venni, jelentősen csökkenthetök a feszültségek és konfliktusok, és országos jelentőségü nagyprojektek finanszírozásának feltételei is biztosíthatók.

A hazai európai uniós támogatással megvalósuló környezetvédelmi infrastruktúra fejlesztési projektek üzemeltetési tapasztalatainak elemzése és értékelése jelentős segítséget jelenthet a további, strukturális alapokból finanszírozott projektek megvalósitása során.

\section{FELHASZNÁLT IRODALOM}

Görög Mihály (2001): Bevezetés a projektmenedzsmentbe, Aula Kiadó, Budapest.

A „Szeged Regionális Hulladékgazdálkodási Programja” dokumentumai 